\title{
Assessing the reduction of the hydrological connectivity of gully systems through vegetation restoration: field experiments and numerical modelling
}

\author{
A. Molina ${ }^{1}$, G. Govers ${ }^{1}$, A. Van den Putte ${ }^{1}$, J. Poesen ${ }^{1}$, and V. Vanacker ${ }^{2}$ \\ ${ }^{1}$ Physical and Regional Geography Research Group, Katholieke Universiteit Leuven, Celestijnenlaan 200E, \\ 3001 Heverlee, Belgium \\ ${ }^{2}$ Department of Geography, University of Louvain, 3 Place Louis Pasteur, 1348 Louvain-la-Neuve, Belgium \\ Received: 7 March 2009 - Published in Hydrol. Earth Syst. Sci. Discuss.: 23 March 2009 \\ Revised: 16 September 2009 - Accepted: 18 September 2009 - Published: 12 October 2009
}

\begin{abstract}
Restoration of degraded land in the Southern Ecuadorian Andes has led to alterations in the functioning of degraded catchments. Recovery of vegetation on areas affected by overgrazing, as well as the reforestation or afforestation of gully areas have given rise to modifications of hydrological connectivity within the catchments. Recent research has highlighted the ability of gully channels to trap sediment eroded from steep slopes, especially if vegetation is established along the gully bed. However, vegetation cover not only induces sediment deposition in the gully bed, but may also have a potential to reduce runoff water volume. The performance of gully beds in reducing the transfer of runoff was investigated by conducting controlled concentrated flow experiments in the field. Experimental field data for nine gullies were derived by pouring concentrated inflow into the upstream end and measuring the outflow at the downstream end of the channel. Two consecutive flow experiments per gully were carried out, so that data for dry and wet soil conditions were collected. The hydrological response to concentrated flow was estimated for each experiment by calculating its cumulative infiltration coefficient, IC (\%). The results showed a great difference in $I C$ between dry and wet soil conditions. The $I C$ for wet soil conditions was on average $24 \%$, whereas it was $60 \%$ for dry conditions. Gullies with more than $50 \%$ surface vegetation cover exhibit the highest cumulative infiltration coefficients ( $81 \%$ for dry runs, and $34 \%$ for wet runs), but runoff transmission losses were not as clearly related to
\end{abstract}

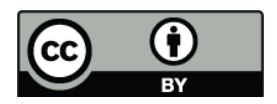

Correspondence to: A. Molina (molina_armando@hotmail.com) vegetation cover as sediment storage as shown in Molina et al. (2009). The experimental field data of 16 experiments were used to calibrate a hydrological model developed by Fiener and Auerswald (2005) in order to simulate the transfer of concentrated flow along the gully beds. The calibrated model was able to simulate the transfer of runoff water well, as the error on the simulated total outflow volumes is below $13 \%$ for 15 out of 16 cases. However, predicting infiltration amounts is difficult: the high sensitivity of model results to some crucial hydraulic parameters (runoff width, hydraulic conductivity and sorptivity) is one of the reasons why the relationships between model parameter values and gully features are relatively weak.

The results obtained from the field experiments show that gully systems are key elements in the hydrological connectivity of degraded landscapes. The transfer of overland flow and sediment from the slopes towards the river system highly depends on the presence/absence of vegetation in the gully beds and should therefore be accounted for in assessments of landscape degradation and/or recovery.

\section{Introduction}

Mountain ecosystems fulfill essential hydrological functions, as they are the source of water for more than half of the global population. Their hydrological functioning is complex, as rainfall-runoff processes are spatially and temporally highly variable and are dependent on topography, vegetation type and cover, lithology, soil and rainfall characteristics (Seibert and MacGlynn, 2005). Under natural conditions,

Published by Copernicus Publications on behalf of the European Geosciences Union. 
humid mountain environments with steep slopes and active slope processes tend to have thin sandy to stony soils and relatively good infiltration rates (Janeau et al., 2003). Land use strongly alters the hydrological functioning of mountain catchments (e.g. Ziegler et al., 2007). Rainfall simulation experiments in heavily disturbed mountainous catchments have demonstrated that the disturbance of natural vegetation changes runoff generation mechanisms (Harden, 1991, 2006; Molina et al., 2007). Soil compaction and truncation following agricultural activities are considered to induce Hortonian overland flow, a phenomenon that is hardly observed in natural mountain forests with the exception of unprotected landslide scars (Bruijnzeel, 2004; Molina et al., 2007; Beck et al., 2008).

The generation of Hortonian overland flow can lead to the development of extensive badlands and gullies on overgrazed and/or abandoned agricultural land. The Hortonian overland flow produced on bare badland slopes disrupt significantly the natural hydrological regime, as badlands not only generate large volumes of water and sediment, but also transport them efficiently to the river network. The dense network of rills and gullies that is often directly connected to tributaries and main river channels plays a key role in connecting sources of water and sediment with the river system (Croke et al., 2005). Any change in the state of the gully network may affect the hydrological connectivity by modifying the transfer of water and sediment from slopes to the river network, and hence influence the hydrological response of the catchment (Bracken and Croke, 2007).

Results from experimental sites have shown that revegetation of the gully bed alters its geomorphological response, and can even make gullies evolve from sediment sources to sediment sinks. Sediment trapping by vegetation in the gully bed was observed for marly gullies with only partial vegetation cover (33\%) in the French Southern Alps (Rey, 2003), for gullies incised in loess (Nachtergaele et al., 2002) as well as for steep afforested gullies in the Ecuadorian Andes (Molina et al., 2009). Several mechanisms co-operate to favour sediment trapping in vegetated gully beds: vegetation generally increases flow resistance, reduces runoff water velocity and sediment transport capacity, thereby inducing sediment deposition (Temple, 1982, 1983; Tsujimoto, 1999; López and García, 2001). The vegetation cover prevents the sediment from being eroded, and its root system anchors the deposited material (Prosser et al., 1995; Rey, 2004). The establishment of grassed waterways in arable land builds on these principles to reduce sediment production and transfer to water bodies (Fiener and Auerswald, 2003; Le Bissonais et al., 2004).

Gully bed stabilization not only affects sediment but also water storage and transmission. However, in spite of the field knowledge gained on gully stabilization following gully bed revegetation (Nachtergaele et al., 2002; Rey, 2003; Molina et al., 2009), quantitative measurements of the effect of the above-described modifications in gully conditions on the hy- drological and sediment connectivity of restored catchments are rare. In this study, we focus on the role of vegetation in modifying the hydrological connectivity of restored gully systems in a partly recovering degraded mountain area. We particularly analysed the performance of gully channels to transfer flow of surface runoff in relation to the vegetation state of the gully channel. Nine gullies were selected representing a wide range in gully bed vegetation cover. Controlled concentrated flow experiments were completed by supplying constant inflow to the upstream end, and measuring flow depth, width and water front advance at several sections as well as the outflow at the downstream end of the gully channel. The experimental data were used to calibrate a hydrological model in order to better understand the physical processes that are controlling infiltration and runoff transmission in gully channels in different development stages. We particularly tested if our modelling approach can be transferred to other gully systems. The results of the model allowed us to quantify the effect of vegetation on runoff transmission for active, transient and passive gully channels. Our modelling approach is based on the concepts developed by Muñoz-Carpena et al. (1993, 1999) and Deletic (2001) for vegetative filter strips and Fiener and Auerswald (2005) for grassed waterways. The model uses the kinematice wave for routing runoff flow, and the Philip's equation for simulating runoff water infiltration.

\section{Materials and methods}

\subsection{Study area}

Nine gullies in the Jadan catchment (Southern Ecuadorian Andes) were selected to represent a wide range in vegetation cover of the gully bed (Fig. 1). Gullies were selected based on the density and age of the gully bed vegetation so that a wide range of vegetated gully systems could be included in the analyses. The observations made for the nine gullies are representative for understanding differences in hydrological connectivity between gully systems in different development stages (see Fig. 2 in Molina et al., 2009). The Jadan catchment is representative for highly degraded Andean ecosystems. The catchment ranges in elevation from 2290 to $3330 \mathrm{~m}$ a.s.l. and has a surface area of $296 \mathrm{~km}^{2}$. The region is characterized by a tropical mountain climate (Dercon et al., 1998). Mean annual rainfall measured at the station of Cochapamba-Quingeo $(2710 \mathrm{~m})$ is about $810 \mathrm{~mm}$, but it is known to be increasing at higher altitudes with a mean annual rainfall of $935 \mathrm{~mm}$ at station of Machangara at $3000 \mathrm{~m}$. The major part of the catchment area comprises lateMiocene to Pliocene volcanoclastic and sedimentary rocks (Hungerbühler et al., 2002). The landscape is dominated by moderate to steep soil-mantled slopes, while several levels of alluvial terraces are present in the Jadan river valley. The gully experiments were carried out in highly eroded 
sites, that have been developed on poorly consolidated and deeply weathered argillites, argillaceous sandstone/siltstone and volcanic deposits. We refer to Molina et al. (2009) for detailed information on gully genesis.

Land use in the Jadan catchment is dynamic and responds quickly to changing socio-economic and demographic settings (White and Maldonado, 1991; Vanacker et al., 2003). Native forest has been transformed into a mosaic of anthropogenic land uses. Today, only some remnants of native forest are present at remote locations at high altitudes. Cleared land is used for intensive crop farming and animal grazing. The reduction of the protective vegetation cover and degradation of the soil chemical and physical properties have accelerated the development of deep gully systems on loosely consolidated and deeply weathered volcanoclastic and sedimentary rocks, especially on the grazing lands (Vanacker et al., 2007). Over the last two decades, declining soil fertility, soil compaction and erosion resulted in increasing land abandonment (Harden, 1996; Vanacker et al., 2003). As a result, the vegetation cover of the lower and middle part of the catchment is now slowly increasing through natural revegetation following abandonment as well as afforestation (Molina et al., 2007).

\subsection{Characterization of the gullies and field measurements}

The upstream area of the nine selected gullies varied from 287 to $934 \mathrm{~m}^{2}$, the gully length ranged from 39 to $59 \mathrm{~m}$, and the average gully bed width ranged from 0.41 to $1.78 \mathrm{~m}$. Each gully was divided into 5-m length segments. For each segment, the ground and canopy vegetation cover, the volume of sediment accumulation, and slope gradient were measured. In the gully beds, a combination of woody vegetation (Alnus jorullensis, Eucalyptus globulus, and Pinus radiate), shrubs (Cortaderia rudiuscula, Spartium junceum and Baccharis polyantha), and grassy plants (Pennisetum clandestinum, Holcus lanatus, Festuca megalura and Cynodon dactylon) are found. The ground vegetation cover of each segment was determined as the percentage of the surface area of the gully bed that is covered by vegetation in contact with the soil surface following the method described in Vanacker et al. (2007). Gully systems were classified in three broad categories (active, transient or passive) according to the stage of gully development (Table 2). We refer to Molina et al. (2009) for a detailed description of the gully characteristics. A total number of 80 gully segments were characterized for this study. Before and after the flow experiments, core samples of the gully bed material were taken using small steel cylinders to determine the grain size distribution of the gully bed material, its moisture content and bulk density.

Flow was released from a $9.850 \mathrm{~m}^{3}$ (2600 US gallons) tank truck, and then transferred to a $1 \mathrm{~m}^{3}$ container through a hose connection. The water level in the latter container was kept as steady as possible using a control valve so that the discharge

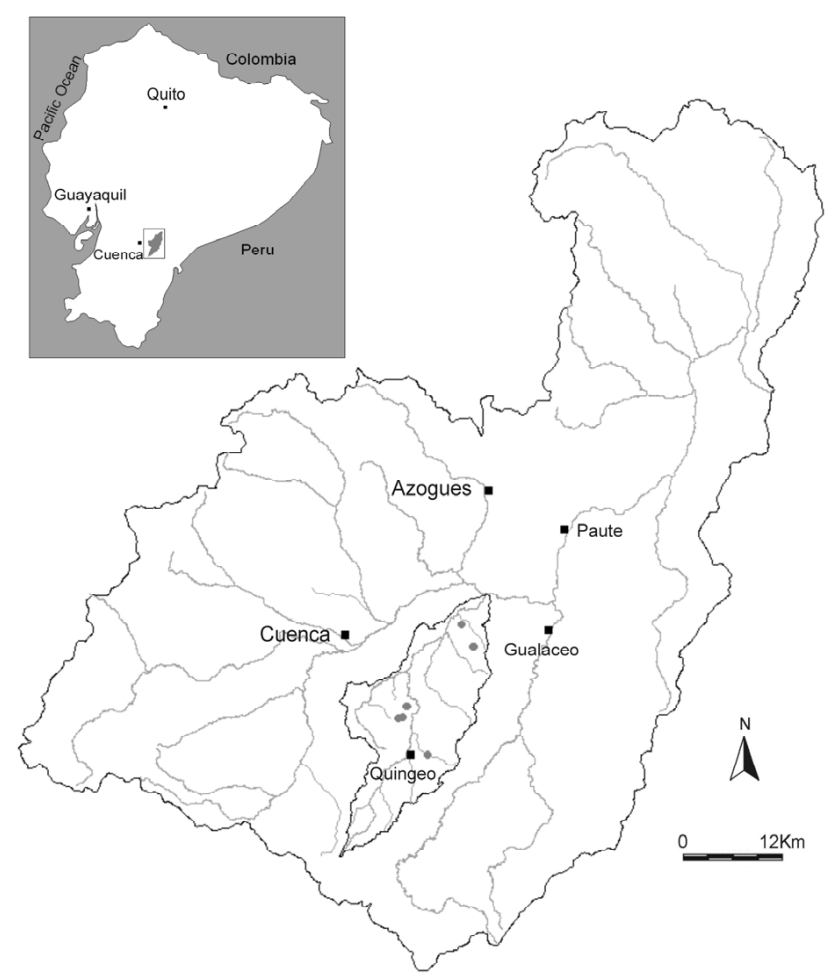

Fig. 1. Study area. The location of the gully systems within the Jadan catchment is given by a grey dot.

supplied to the upstream end of the gully channel was as constant as possible (Fig. 2). At the gully outlet an H-flume was installed in order to measure outflowing discharge. From the start of the concentrated flow measurements, we monitored the advance of the water front. Based on the distance travelled during a certain time interval, we calculated the rate of advance of the water front. At regular time intervals, we also measured flow depth and width at several locations along the gully bed. The mean flow velocity, $V\left(\mathrm{~m} \mathrm{~s}^{-1}\right)$, was estimated using Manning's formula:

$V=\frac{R^{2 / 3} S_{\text {gully }}^{1 / 2}}{n}$

Where $n$ is the Manning's roughness coefficient $\left(\mathrm{s} \mathrm{m}^{-1 / 3}\right), R$ is the hydraulic radius (m), and $S_{\text {gully }}$ is the linear hydraulic head loss approximated by the slope gradient of the gully bed $\left(\mathrm{m} \mathrm{m}^{-1}\right)$. The Manning's roughness coefficient for vegetation was estimated following the procedure for additive resistance developed by Cowan (1956):

$n=\left(n_{0}+n_{1}+n_{2}+n_{3}+n_{4}\right) m$

where $n_{0}$ is the base value for a straight, uniform, smooth channel in natural materials, $n_{1}$ is an additive value to account for surface irregularities, $n_{2}$ is added to account for variations in the channel geometry along the reach, $n_{3}$ is an additive value to account for obstructions, $n_{4}$ accounts for 


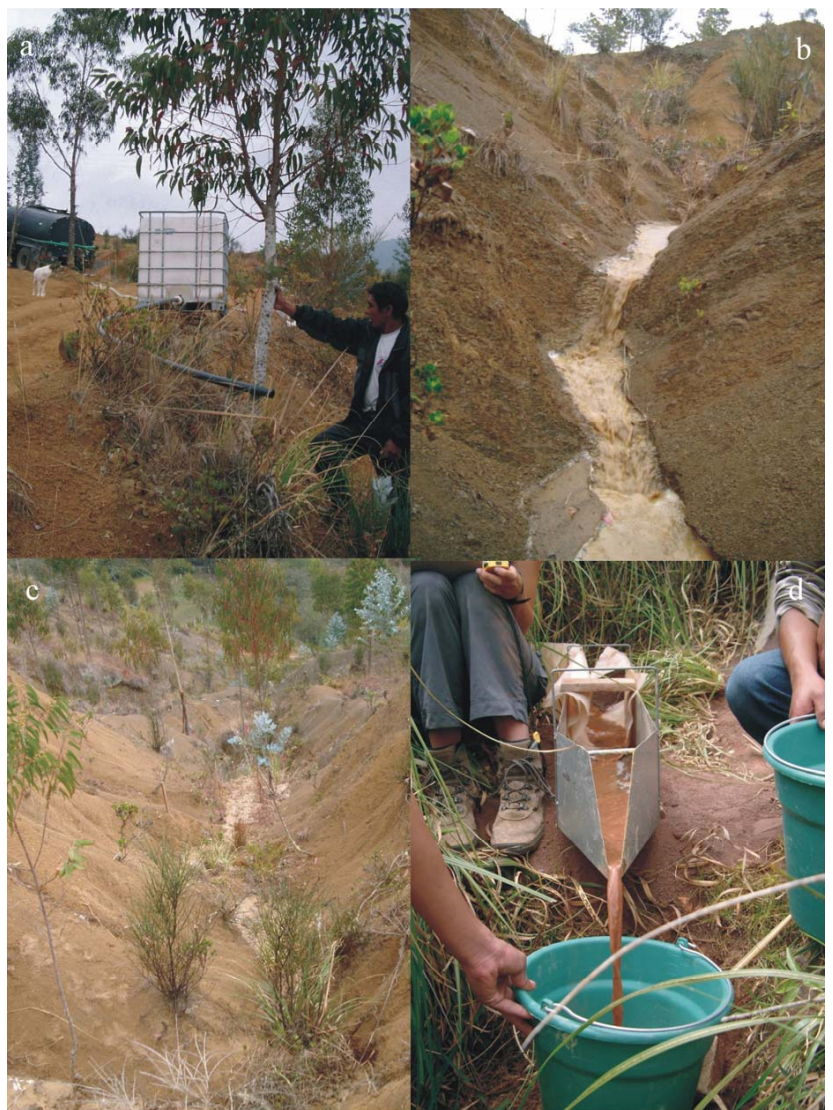

Fig. 2. Experimental design of the concentrated flow experiments with (a) water supply from water tank, (b) and (c) concentrated flow in the gully floor, and (d) collection of runoff water and sediment.

vegetation, and $m$ is a correction factor for meandering or sinuosity of the channel. The results of the roughness coefficient estimation are given in Table 4.

Two consecutive flow experiments were carried out per gully, in order to collect data for dry and wet soil conditions. The experimental data are summarized in Table 2. As the experiments were realised in the dry season, all but one first flow experiments were conducted in completely dry conditions. The gully bed of Carmenjadan1 was slightly wet during the first flow experiment, which is reflected in a higher soil moisture content during the dry run. Each experimental run lasted between 20 and $55 \mathrm{~min}$. For the wet runs, this was sufficient to reach a steady-state discharge at the gully outlet.

\subsection{Model description}

The model that was developed for simulating routing of concentrated flow in gully beds is conceptually similar to the model of Fiener and Auerswald (2005) for grassed waterways on agricultural land. For a detailed description of the model we refer to Fiener and Auerswald (2005). Figure 3 is a schematic illustration of this model framework. We divided each gully into $\mathrm{n}$ segments of length $\Delta x$. A finite differ- ence scheme is used to route runoff water through the gully system, accounting for (I) surface infiltration, (II) filling of surface storage and (III) surface runoff.

\subsubsection{Infiltration}

Infiltration in the gully bed depends on the bed material, and its moisture content. To simplify the hydrological model, we assume that vertical infiltration is the dominant infiltration process, and that horizontal infiltration is negligible. Fiener and Auerswald (2005) adopted the Philip's equation (Eq. 3) as infiltration component of the model, which is a mathematical solution of the Richard's equation applied to vertical infiltration (Philip, 1969; Hillel, 1998):

$i(t)=\frac{1}{2 \cdot \sqrt{t}} \cdot S+K$

where $i(t)$ is the infiltration rate $\left(\mathrm{m} \mathrm{s}^{-1}\right), t$ is the time (s), $S$ is the sorptivity $\left(\mathrm{m} \mathrm{s}^{-0.5}\right.$ ), and $K$ is the hydraulic conductivity $\left(\mathrm{m} \mathrm{s}^{-1}\right)$.

\subsubsection{Surface retention}

Surface retention is the amount of water that is stored above ground in small micro-depressions. This storage volume depends on the roughness of the gully bed, its vegetative cover and slope. Deletic (2001) showed that surface retention in grassed areas can be substantial, and often equal in magnitude to the total depth of a small to medium rainfall event. Here, we follow the approach of Fiener and Auerswald (2005) developed for grassed waterways and estimated the surface retention volume as the product of the measured average flow depth and the wetted surface area. As most of the ground vegetation cover in the studied gully beds consists of grassy plants, this approach is considered to be appropriate.

\subsubsection{Surface runoff}

Unsteady flow in open channels is commonly described by one-dimensional Saint-Venant equations (1881) and based on the equations of continuity (Eq. 4) and momentum (Eq. 5) (Chow et al., 1988):

$$
\begin{aligned}
& \frac{\partial Q}{\partial x}+\frac{\partial A}{\partial t}=q \\
& \frac{\partial V}{\partial t}+V \cdot \frac{\partial V}{\partial x}+g \cdot \frac{\partial y}{\partial x}=g \cdot\left(S_{\text {gully }}-S_{f}\right)
\end{aligned}
$$

where $Q(x, t)$ is the discharge $\left(\mathrm{m}^{3} \mathrm{~s}^{-1}\right), A(x, t)$ is the crosssectional area of the flow $\left(\mathrm{m}^{2}\right), x$ is the distance in flow direction $(\mathrm{m}), t$ is the time (s), $q$ is the lateral inflow $\left(\mathrm{m}^{2} \mathrm{~s}^{-1}\right)$, $V$ is the average flow velocity $\left(\mathrm{m} \mathrm{s}^{-1}\right), g$ is the gravitational acceleration $\left(\mathrm{m} \mathrm{s}^{-2}\right), y$ is the flow depth (m), $S_{\text {gully }}$ is the dimensionless bed slope and $S_{f}$ is the dimensionless friction slope. 
In this work, we used kinematic flow approximations to simulate the flow of runoff water in gully channels. Kinematic flow routing is a simplification of the Saint-Venant equations of one-dimensional flow (Lighthill and Woolhiser, 1955). In kinematic flow conditions, the weight component of the flow (gravity force) is approximately balanced by the flow resistance (friction force) due to channel bed friction. A kinematic wave appears as uniform unsteady flow in the channel bed, and water and channel bed surfaces are considered to be parallel to each other and to the energy grade line. This routing scheme was already successfully applied for modelling surface runoff in grassed waterways (Fiener and Auerswald, 2005) and vegetated filter strips (MuñozCarpena et al., 1993, 1999; Deletic, 2001). As we are working here in steep gully channels with no back water effect, kinematic flow approximations are particularly suitable.

By applying a kinematic wave approach, the momentum equation (Eq. 5) is replaced by a unique relation between the mean velocity and the flow depth. By doing so, only the gravity and friction slope terms are retained, and the momentum equation is reduced to $S_{\text {gully }}=S_{f}$. The discharge $Q$ can be expressed combining the Manning's Eq. (1) with $v=Q / A$ to yield Eq. (6):

$Q=\frac{S_{\text {gully }}^{1 / 2} R^{2 / 3} A}{n}$

where $Q$ is the discharge $\left(\mathrm{m}^{3} \mathrm{~s}^{-1}\right), n$ is the Manning's roughness coefficient $\left(\mathrm{m} \mathrm{s}^{-1 / 3}\right)$ dependent on soil surface condition and vegetative cover, $S_{\text {gully }}$ is the linear hydraulic head loss approximated by the slope gradient of the gully bed $\left(\mathrm{m} \mathrm{m}^{-1}\right), R$ is the hydraulic radius $(\mathrm{m})$ and $A$ is the crosssectional area of flow $\left(\mathrm{m}^{2}\right)$. We replaced the hydraulic radius, $R$, by $A / w$, with $A$ the cross-sectional area and $w$ the hydraulic perimeter $(\mathrm{m})$. The Manning's equation can then be written as

$A=\left[\frac{n \cdot w^{2 / 3}}{S_{\text {gully }}^{1 / 2}}\right]^{3 / 5} \cdot Q^{3 / 5}$

Assume now that:

$\alpha=\left[\frac{n \cdot w^{2 / 3}}{S_{\text {gully }}^{1 / 2}}\right]^{3 / 5}$

And:

$\beta=\frac{3}{5}$, then $A=\alpha \cdot Q^{\beta}$

The continuity equation (Eq. 4) can then be written in function of a single dependent variable (Chow et al., 1988).

$\frac{\partial Q}{\partial x}+\alpha \beta Q^{\beta-1} \frac{\partial Q}{\partial t}=q$
This simplified form of the kinematic wave equation (Eq. 8) describes the distribution of flow as function of the distance $x$ along the channel bed and the time $t$.

The use of the Manning's equation can be questioned, as it is well known that it does not describe well flow on steep slopes in eroding rills and gullies (Govers et al., 2007). However, most systems studied here are at present not subject to erosion, as the presence of vegetation induces sedimentation and the bed could be considered to be more or less stable during most of our experiments. Under these conditions, the Manning's equation may be used, even on steep slopes (Gimenez and Govers, 2001).

We solved the kinematic wave equation numerically using an explicit finite difference approach. Figure 4 illustrates the outline of the computational grid that we used for discretization of the continuity equation. Our approximation uses the initial input parameters of $\alpha, \beta$, and $q$ (lateral inflow), and estimates the partial derivatives, $(\delta Q / \delta x)$ and $(\delta Q / \delta t)$, using a forward difference approximation. The value of $Q$ in the term $\alpha \beta Q^{\beta-1}$ was estimated as an average of the $Q(x, t)$ values along the diagonal (Fig. 4). Hence, the following formula is obtained for estimating $Q_{i+1}^{j+1}$.

$Q_{i+1}^{j+1}=\frac{\frac{\Delta t}{\Delta x} Q_{i}^{j+1}+\alpha \beta Q_{i+1}^{j}\left(\frac{Q_{i}^{j+1}+Q_{i+1}^{j}}{2}\right)^{\beta-1}+q \Delta t}{\frac{\Delta t}{\Delta x}+\alpha \beta\left(\frac{Q_{i}^{j+1}+Q_{i+1}^{j}}{2}\right)^{\beta-1}}$

It is known that solving the continuous kinematic wave equation by finite differences can introduce numerical errors into the results which can be amplified with successive calculations (Jaber and Mohtar, 2002). We avoided numerical instability by taking small values of $\Delta x(5 \mathrm{~m})$ and $\Delta t(5 \mathrm{~s})$. This resulted in a Courant number always well below 1 .

\subsubsection{Parametrization}

The input parameters for the kinematic wave model are listed in Table 1. Various parameters were directly measured in the field during the flow experiments, such as the inflow rates at the upstream end of the gully channel, the flow depth and flow width at several locations along the gully bed and the slope of the gully bed. The Manning's roughness coefficient, $n$, was calculated using Eq. (2) based on reference values for $n_{0-4}$ published by Cowan (1956). The lateral inflow rate, $q$, is computed as the sum of the rainfall rate and the outflow rate from the upstream gully segment. As the experiments were carried out in dry weather conditions, the lateral inflow rate equals the outflow rate of the upstream gully segment (Fig. 3). The time-dependent infiltration function, here described by the Philip's equation (Eq. 3), was solved for each grid point of the computational grid. The values of sorptivity, $S$, and hydraulic conductivity, $K$, were calibrated to observed outflow hydrographs. As the lateral flow parameter of the kinematic wave model $(q)$ is expressed in $\mathrm{m}^{3} \mathrm{~m}^{-1} \mathrm{~s}^{-1}$ 
Table 1. Input parameters of the flow model.

\begin{tabular}{llcll}
\hline Characteristics & Parameter & Symbol & Unit & Range \\
\hline Soil & Hydraulic conductivity & $K$ & $\mathrm{~m} \mathrm{~s}^{-1}$ & $1.0 \times 10^{-8}-4.8 \times 10^{-5}$ \\
& Sorptivity & $S$ & $\mathrm{~m} \mathrm{~s}^{-0.5}$ & $9.0 \times 10^{-6}-1.05 \times 10^{-3}$ \\
\hline Vegetation & Manning's roughness & $n$ & $\mathrm{~s} \mathrm{~m}^{-1 / 3}$ & $9.1 \times 10^{-2}-2.52 \times 10^{-1}$ \\
& coefficient & & & \\
\hline Hydrology & Hydraulic radius & $R$ & $\mathrm{~m}$ & $0.032-0.15$ \\
& Average runoff width & $W$ & $\mathrm{~m}$ & $0.51-1.09$ \\
& Average flow depth & $y$ & $\mathrm{~m}$ & $0.035-0.37$ \\
& $\begin{array}{l}\text { Distance in flow } \\
\text { direction }\end{array}$ & $x$ & $\mathrm{~m}$ & 5 \\
& Average flow velocity & $V$ & $\mathrm{~m} \mathrm{~s}^{-1}$ & $0.261-1.394$ \\
& Average bed slope & $S_{\text {gully }}$ & $\mathrm{m} \mathrm{m}^{-1}$ & $0.14-0.56$ \\
& Inflow & $Q$ & $\mathrm{~m}^{3} \mathrm{~s}^{-1}$ & $0.0019-0.0027$ \\
\hline
\end{tabular}

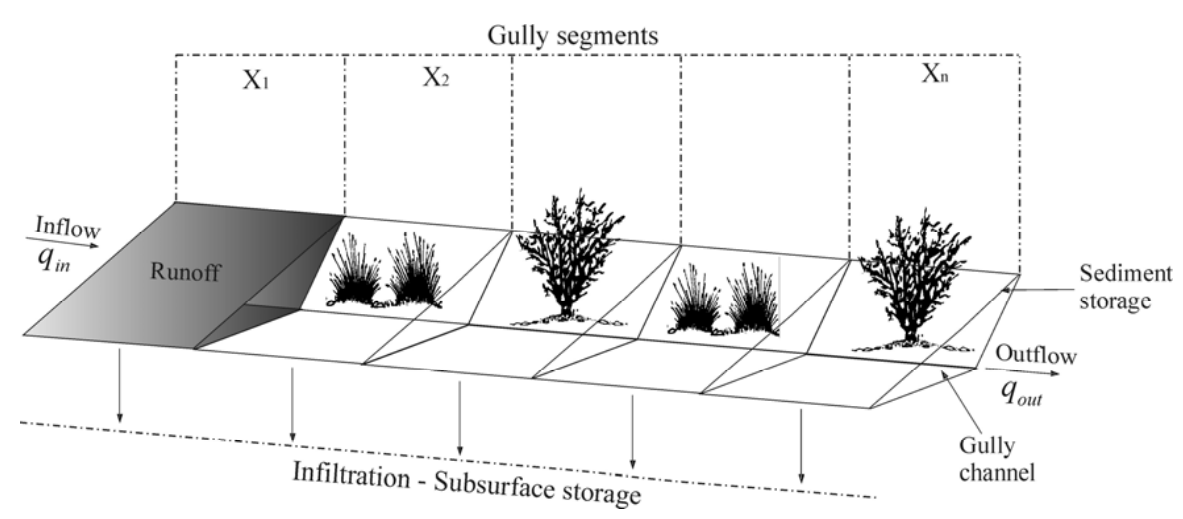

Fig. 3. Schematic illustration of model components.

(i.e. the lateral flow per gully bed length per time unit), the values obtained by solving the Philip's equation (i.e. infiltration rate per surface area per time unit, $\left.\mathrm{m}^{3} \mathrm{~m}^{-2} \mathrm{~s}^{-1}\right)$, were multiplied with the corresponding gully bed width.

\section{Analysis and discussion of experimental data}

\subsection{Role of vegetation on infiltration and runoff transfer}

We completed 18 concentrated flow experiments, one experiment under dry and wet conditions for each gully: 17 out of 18 experiments resulted in outflow at the downstream end of the gully channel. For the Quingeo gully, the amount of water supplied in the dry run was unable to produce any outflow. Furthermore, we noticed that the transmission of runoff was spatially very heteregeneous in this gully, with a rapid water transfer in the upper part and a very slow transmission in the lower, heavily vegetated part. We therefore did not take the results from this gully into account in the further analy- sis as the spatial heterogeneity within the gully is too big to considered it as a single system. Thus, 16 observations were retained for further analysis.

The total inflow, $R I\left(\mathrm{~m}^{3}\right)$, varied from 1.67 to $5.99 \mathrm{~m}^{3}$, with an average value of $2.93 \mathrm{~m}^{3} \pm 1.19$ (1 s.d.), and the total outflow, $R O\left(\mathrm{~m}^{3}\right)$, varied from 0.19 to $3.54 \mathrm{~m}^{3}$, with an average value of $1.49 \mathrm{~m}^{3} \pm 0.76$ (Table 2). The hydrological response to concentrated flow was estimated for each experiment by calculating the cumulative infiltration coefficient, $I C$ $(\%)$ :

$I C=[(R I-R O) / R I] \times 100$

Clear differences in cumulative infiltration were observed for experiments under dry and wet hydrological conditions (Table 2). Cumulative infiltration coefficients measured under dry conditions varied between 34 and $100 \%$, with an average value of $60 \% \pm 23$ ( 1 s.d.); whereas the coefficients under wet conditions ranged between 1 and $70 \%$, with an average of $24 \% \pm 19$. 
Table 2. Summary of the experimental data of the concentrated flow experiments (GDS=Gully development stage; $S_{\text {gully }}=$ Average bed slope, $\mathrm{m} \mathrm{m}^{-1} ; W=$ Average runoff width, $\mathrm{m}$; and Sand, Silt and Clay represent the $\%$ of the bed material composed of sand, silt and clay fraction respectively; $R I=$ Total inflow volume, $\mathrm{m}^{3} ; R O=$ Total outflow volume, $\mathrm{m}^{3} ; I=$ Total infiltration volume, $\mathrm{m}^{3} ; I C=$ Cumulative infiltration coefficient, $\% ; V C=$ Average vegetation cover, $\% ; A S M=$ Antecedent soil moisture, $\%$ ).

\begin{tabular}{|c|c|c|c|c|c|c|c|c|c|c|c|c|}
\hline Location & $G D S$ & $S_{\text {gully }}$ & $W$ & Sand & Silt & Clay & $R I$ & $R O$ & $I$ & $I C$ & $V C$ & $A S M$ \\
\hline Carmenjadan1 & Passive & 0.24 & 0.81 & 43 & 48 & 9 & & & & & & \\
\hline Dry run & & & & & & & 2.77 & 1.44 & 1.33 & 48 & 70 & 49 \\
\hline Wet run & & & & & & & 2.14 & 2.11 & 0.03 & 1 & 70 & 56 \\
\hline Carmenjadan2 & Transient & 0.20 & 0.51 & 29 & 56 & 15 & & & & & & \\
\hline Dry run & & & & & & & 3.37 & 2.00 & 1.37 & 41 & 24 & 30 \\
\hline Wet run & & & & & & & 1.90 & 1.49 & 0.41 & 22 & 24 & 55 \\
\hline Jadan1 & Passive & 0.59 & 0.77 & 45 & 40 & 15 & & & & & & \\
\hline Dry run & & & & & & & 3.79 & 0.19 & 3.59 & 95 & 77 & 10 \\
\hline Wet run & & & & & & & 2.20 & 0.67 & 1.54 & 70 & 77 & 14 \\
\hline Jadan2 & Transient & 0.57 & 1.09 & 32 & 53 & 15 & & & & & & \\
\hline Dry run & & & & & & & 2.57 & 1.69 & 0.88 & 34 & 43 & 6 \\
\hline Wet run & & & & & & & 2.06 & 1.84 & 0.22 & 11 & 43 & 16 \\
\hline Mosquera1 & Transient & 0.41 & 0.66 & 14 & 52 & 34 & & & & & & \\
\hline Dry run & & & & & & & 2.80 & 1.40 & 1.40 & 50 & 35 & 12 \\
\hline Wet run & & & & & & & 2.02 & 1.61 & 0.41 & 20 & 35 & 29 \\
\hline Mosquera2 & Active & 0.28 & 0.55 & 55 & 36 & 9 & & & & & & \\
\hline Dry run & & & & & & & 3.04 & 1.15 & 1.89 & 62 & 12 & 11 \\
\hline Wet run & & & & & & & 1.99 & 1.60 & 0.39 & 20 & 12 & 38 \\
\hline Sanmiguel1 & Transient & 0.28 & 0.62 & 4 & 55 & 41 & & & & & & \\
\hline Dry run & & & & & & & 3.84 & 1.63 & 2.21 & 58 & 34 & 14 \\
\hline Wet run & & & & & & & 1.92 & 1.51 & 0.41 & 21 & 34 & 34 \\
\hline Sanmiguel2 & Active & 0.36 & 0.60 & 47 & 38 & 15 & & & & & & \\
\hline Dry run & & & & & & & 3.47 & 1.65 & 1.82 & 52 & 3 & 15 \\
\hline Wet run & & & & & & & 1.67 & 1.38 & 0.29 & 17 & 3 & 29 \\
\hline Quingeo & Passive & 0.14 & - & - & - & - & & & & & & \\
\hline Dry run & & & & & & & 5.99 & 0.00 & 5.99 & 100 & 59 & - \\
\hline Wet run & & & & & & & 5.22 & 3.54 & 1.68 & 32 & 59 & - \\
\hline
\end{tabular}

Next to its hydrological condition, the vegetation cover of the gully bed largely affects surface runoff transmission. The formation of vegetated buffer zones in the gully bed increases roughness, retards runoff velocity, disperses flow, and promotes infiltration and deposition of sediment. Plants remove water from the soil, enhancing the capacity to absorb water. Gullies with more than $50 \%$ vegetation cover (Carmenjadan1, Jadan1 and Quingeo) have the highest cumulative infiltration coefficients: under dry hydrological conditions, $81 \%$ of the total surface runoff infiltrated in the gully bed. This value is reduced to $34 \%$ in more moist conditions. Sparsely vegetated gullies, such as Mosquera2 and Sanmiguel 2 with vegetation cover below $15 \%$, are characterized by low infiltration coefficients of about $50 \%$ under dry conditions, and about $19 \%$ under wet conditions.
Infiltration also increased with increasing runoff width. This is to be expected, given the fact that the water can infiltrate over a large area if the runoff width is larger. Linear regression reveals that ca. $78 \%$ of the variance in cumulative infiltration coefficient was explained by vegetation cover, runoff width and antecedent moisture content (Tables 2 and 3 ). Thus, apart from vegetation cover, soil moisture conditions and gully geometry also strongly affect water infiltration into the gully bed. 
Table 3. Results of the multiple regression analysis for the simulation of the cumulative infiltration coefficient, $I C$. The uncertainty on the model fit is given by the partial and model R-Square.

\begin{tabular}{llrccc}
\hline & & $\begin{array}{r}\text { Parameter } \\
\text { estimate }\end{array}$ & p value & $\begin{array}{c}\text { Partial } \\
\text { R-Square }\end{array}$ & $\begin{array}{c}\text { Model } \\
\text { R-Square }\end{array}$ \\
\hline Antecedent soil moisture & $A S M$ & -1.270 & $<0.001$ & 0.348 & 0.348 \\
Average vegetation cover & $V C$ & 0.754 & 0.0007 & 0.109 & 0.457 \\
Runoff width & $W$ & -102.049 & 0.0011 & 0.326 & 0.784 \\
\hline
\end{tabular}

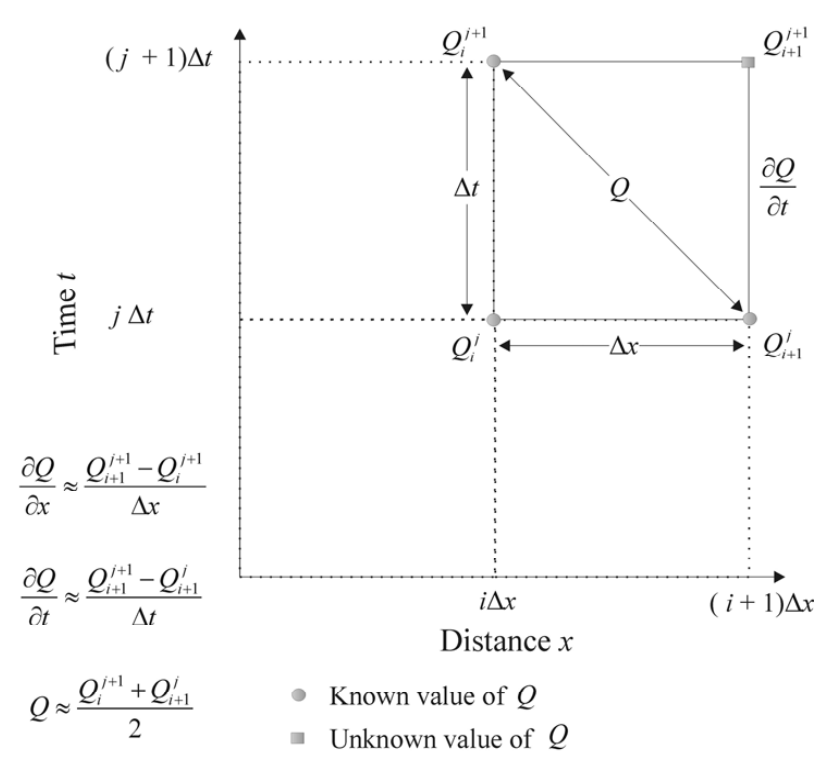

Fig. 4. Outline of the computational grid used to solve the kinematic wave equation (after Chow et al., 1988).

\section{Numerical modeling of runoff transfer in gully channels}

\subsection{Model calibration}

The kinematic wave model was calibrated manually for each flow experiment by adjusting the values of sorptivity, $S$, and hydraulic conductivity, $K$, in order to match as closely as possible the observed outflow hydrographs (Table 4, Fig. 5). The value of sorptivity was adjusted between $4.2 \times 10^{-4}$ and $1.1 \times 10^{-3}$ for dry conditions and between $9 \times 10^{-6}$ and $7.2 \times 10^{-4}$ for wet conditions; and the hydraulic conductivity between $6.4 \times 10^{-7}-4 \times 10^{-5}$ for dry conditions and between $9.9 \times 10^{-8}-4.8 \times 10^{-5}$ for wet conditions. Three goodnessof-fit parameters were used to evaluate the quality of the modeling results: (I) the root mean square error (RMSE), (II) the coefficient of determination $\left(R^{2}\right)$ and (III) the model efficiency (ME, Tables 4 and 5). Figure 6a shows that the model is able to simulate the transfer of runoff water generally well, with a slight tendency to underpredict the total outflow vol- umes. The statistical results obtained with the optimal parameter values show a RMSE of 0.13 , a $R^{2}$ of 0.91 and a ME of 0.92. One experiment, the San Miguel2 "wet run", shows an error on the simulated outflow volume of $23 \%$, which is mainly due to an overestimation by the model of the infiltration after the end of inflow. The tendency of the model to underpredict the total outflow volumes for active and transient gully systems is mainly related to a poor representation of the hydrological conditions along the gully bed. The San Miguel2 gully has steep slopes, and its gully channel is very sparsely vegetated (average vegetation cover of 3\%) : therefore only a thin sediment layer $(<0.1 \mathrm{~m})$ was present on the bed. Below this sediment layer impermeable bedrock was present which was locally exposed due to erosion occurring during the dry run. The Philip's infiltration model assumes a homogeneous, deep soil profile and is therefore not suitable for conditions under which saturation overland flow may occur, leading to an overestimation of infiltration.

\subsection{Sensitivity analysis}

The sensitivity of the model simulations to variations in the input parameters of the Manning's roughness coefficient $n$, sorptivity $S$, hydraulic conductivity $K$ and runoff width $W$ was analysed for the Jadan1 experiment for both dry and wet conditions. An individual parameter sensitivity analysis was performed by varying one input parameter at a time, starting with the initial values (Table 4). As the presence of vegetation in the gully bed affects both the runoff width and the Manning's roughness coefficient $n$, we also conducted a sensitivity analysis by varying Manning's $n$ and runoff width $W$ simultaneously. The percentage of change both in total runoff volume and in the simulation of the time to runoff was calculated once the parameters were varied. With variations in the range of model input parameters, the range of computed flow hydrographs at the downstream end of the gully channel was analysed. We chose values of Manning's $n$ of $0.02 \mathrm{~m} \mathrm{~s}^{-1 / 3}$ for an unvegetated gully bed and $0.3 \mathrm{~m} \mathrm{~s}^{-1 / 3}$ for a fully vegetated gully bed.

The simulation of the time to runoff and the total runoff volume are highly sensitive to the input parameters for $S$, $K$ and $W$ (Fig. 7). The sensitivity of the model is clearly highest for dry conditions. A $10 \%$ decrease in $S$ translates 
DRY RUN

A

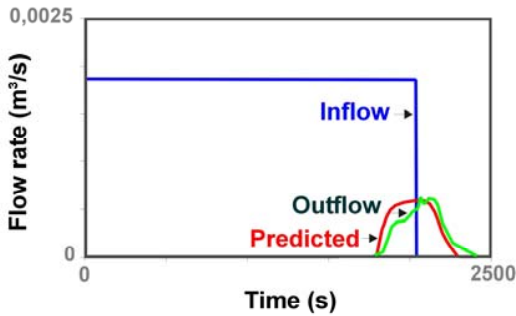

B

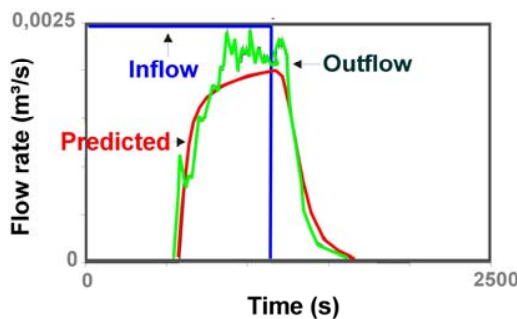

C

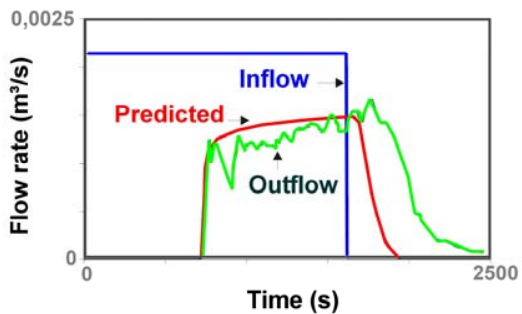

WET RUN
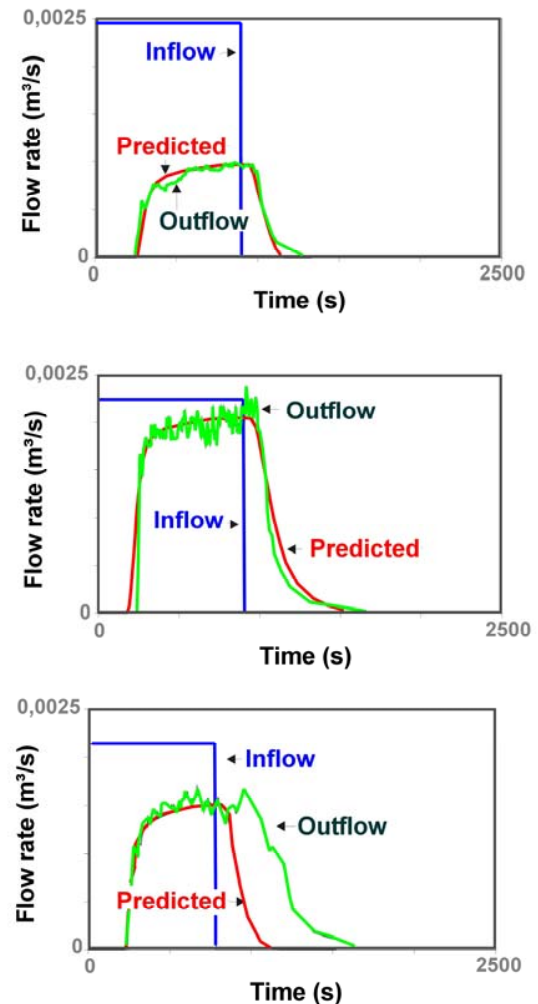

Fig. 5. Observed and computed flow hydrograph for three gullies with distinct vegetation cover of the gully bed. (A) Jadan1: dense vegetation cover. (B) Mosquera1: intermediate vegetation cover. (C) San Miguel2: very low vegetation cover of gully bed).

into a $330 \%(5 \%)$ increase in runoff volume and $57 \%(8 \%)$ decrease in time to runoff for dry (wet) conditions, whereas a $20 \%$ decrease in $S$ translates into a $425 \%(10 \%)$ increase in runoff volume and $72 \%(14 \%)$ decrease in time to runoff (Fig. 7a). An increase in $S$ of only $10 \%$ prevents the model to produce any outflow in dry conditions, and leads to a $6 \%$ decrease in runoff volume and a $10 \%$ increase in time to runoff in wet conditions. Similar observations were made for $W$ : a $30 \%$ decrease in $W$ translates into a $600 \%$ (40\%) increase in runoff volume and $75 \%(24 \%)$ decrease in time to runoff while a $40 \%$ decrease in $W$ translates into a $810 \%(68 \%)$ increase in runoff volume and $84 \%(38 \%)$ decrease in time to runoff for dry (wet) conditions (Fig. 7b). When increasing $W$ by $10 \%$, the model does not simulate any outflow. By changing the parameter value of $K$ by $-10 \%$, the computed runoff volume increased by $340 \%(17 \%)$ and the time to runoff decreased by $50 \%(8 \%)$, whereas a $20 \%$ decrease in $K$ translates into a $515 \%(34 \%)$ increase in runoff volume and $65 \%$ (14\%) decrease in time to runoff (Fig. 7c). On the other hand, a $3 \%$ increase in $K$ results in the simulation of no runoff for dry conditions and in a slight decrease in runoff volume and small increase in time to runoff for wet conditions. On the other hand, a $92 \%$ decrease in $n$ (for the unvegetated gully bed scenario, $n=0.02 \mathrm{~m} \mathrm{~s}^{-1 / 3}$ ) translates in a $35 \%(8 \%)$ in- crease in runoff volume and an $11 \%(56 \%)$ decrease in time to runoff only for dry (wet) gully bed conditions. A $19 \%$ increase in $n$ (for the fully vegetated scenario, $0.3 \mathrm{~m} \mathrm{~s}^{-1 / 3}$ ) translates into a $5 \%(2 \%)$ decrease in runoff volume and $2 \%$ $(14 \%)$ increase in time to runoff.

As a change of vegetation in the gully bed not only affects the roughness coefficient $n$ but also the flow width $W$, we analysed the combined effect of both parameters. Our results indicate that both the outflow volume and the time to runoff are highly sensitive to these changes : a reduction in runoff width by $30 \%$ and in $n$ by $92 \%$ results in a strong increase in runoff volume by more than $600 \%$ and a reduction in time to runoff by $83 \%$. Here, we also note that the model is clearly most sensitive to variations in the input parameters $W$ and $n$ for dry conditions. We observe that there is some dependency among the input parameters $W$ and $n$, as the total variability on outflow volume and time to runoff is lower than the sum of the individual variabilities. The strong interaction of vegetation with runoff width is likely to be the main reason for the marginal sensitivity of the model to changes in Manning's $n$. 
Table 4. Results of the kinematic flow model for each gully system with indication of the calibrated and simulated parameter values and outflow. $K_{2}$ and simulated outflow ${ }_{S}$ were obtained after a second model optimisation keeping the sorptivity, $S$, constant. The values of simulated outflow ${ }_{K}$ were obtained using the predicted values of hydraulic conductivity after Eq. (11).

\begin{tabular}{|c|c|c|c|c|c|c|c|c|}
\hline Location & $\begin{array}{c}n \\
\mathrm{~s} \mathrm{~m}^{-1 / 3}\end{array}$ & $\begin{array}{c}S \\
\mathrm{~m} \mathrm{~s}^{-0.5}\end{array}$ & $\begin{array}{c}K \\
\mathrm{~m} \mathrm{~s}^{-1}\end{array}$ & $\begin{array}{c}\text { Measured } \\
\text { outflow } \\
\mathrm{m}^{3}\end{array}$ & $\begin{array}{c}\text { Simulated } \\
\text { outflow } \\
\mathrm{m}^{3}\end{array}$ & $\begin{array}{c}K_{2} \\
\mathrm{~m} \mathrm{~s}^{-1}\end{array}$ & $\begin{array}{c}\text { Simulated } \\
\text { Outflow }{ }_{S} \\
\mathrm{~m}^{3}\end{array}$ & $\begin{array}{c}\text { Simulated } \\
\text { Outflow } K 2 \\
\mathrm{~m}^{3}\end{array}$ \\
\hline \multicolumn{9}{|l|}{ Carmenjadan1 } \\
\hline Dry run & 0.231 & $5.1 \times 10^{-4}$ & $1.0 \times 10^{-6}$ & 1.44 & 1.31 & $9.7 \times 10^{-6}$ & 1.09 & 0.58 \\
\hline $\begin{array}{l}\text { Wet run } \\
\text { Carmenjadan2 }\end{array}$ & 0.212 & $1.2 \times 10^{-4}$ & $2.0 \times 10^{-7}$ & 2.11 & 2.18 & $1.0 \times 10^{-6}$ & 1.49 & 1.06 \\
\hline Dry run & 0.169 & $1.1 \times 10^{-3}$ & $1.1 \times 10^{-6}$ & 2.00 & 1.83 & $1.0 \times 10^{-5}$ & 2.71 & 2.98 \\
\hline $\begin{array}{l}\text { Wet run } \\
\text { Jadan1 }\end{array}$ & 0.160 & $7.2 \times 10^{-4}$ & $5.0 \times 10^{-7}$ & 1.49 & 1.42 & $1.0 \times 10^{-5}$ & 1.46 & 1.62 \\
\hline Dry run & 0.252 & $5.2 \times 10^{-4}$ & $4.0 \times 10^{-5}$ & 0.19 & 0.20 & $4.6 \times 10^{-5}$ & 0.14 & 0.91 \\
\hline $\begin{array}{l}\text { Wet run } \\
\text { Jadan2 }\end{array}$ & 0.230 & $3.8 \times 10^{-4}$ & $4.8 \times 10^{-5}$ & 0.67 & 0.68 & $4.7 \times 10^{-5}$ & 0.63 & 0.86 \\
\hline Dry run & 0.230 & $6.0 \times 10^{-4}$ & $6.4 \times 10^{-7}$ & 1.69 & 1.56 & $2.4 \times 10^{-5}$ & 0.80 & 0.63 \\
\hline $\begin{array}{l}\text { Wet run } \\
\text { Mosquera1 }\end{array}$ & 0.214 & $9.0 \times 10^{-6}$ & $7.0 \times 10^{-6}$ & 1.84 & 1.74 & $9.0 \times 10^{-7}$ & 1.21 & 0.37 \\
\hline Dry run & 0.195 & $7.2 \times 10^{-4}$ & $9.9 \times 10^{-7}$ & 1.40 & 1.45 & $1.0 \times 10^{-6}$ & 2.18 & 1.42 \\
\hline $\begin{array}{l}\text { Wet run } \\
\text { Mosquera2 }\end{array}$ & 0.182 & $3.0 \times 10^{-4}$ & $9.9 \times 10^{-8}$ & 1.61 & 1.70 & $1.0 \times 10^{-6}$ & 1.44 & 1.15 \\
\hline Dry run & 0.157 & $4.2 \times 10^{-4}$ & $3.7 \times 10^{-5}$ & 1.15 & 1.10 & $3.6 \times 10^{-5}$ & 1.10 & 1.62 \\
\hline $\begin{array}{l}\text { Wet run } \\
\text { Sanmiguel1 }\end{array}$ & 0.155 & $2.0 \times 10^{-4}$ & $9.0 \times 10^{-6}$ & 1.60 & 1.63 & $1.0 \times 10^{-6}$ & 1.60 & 1.38 \\
\hline Dry run & 0.185 & $6.2 \times 10^{-4}$ & $1.9 \times 10^{-5}$ & 1.63 & 1.72 & $2.2 \times 10^{-5}$ & 1.98 & 2.44 \\
\hline $\begin{array}{l}\text { Wet run } \\
\text { Sanmiguel2 }\end{array}$ & 0.177 & $9.0 \times 10^{-5}$ & $8.0 \times 10^{-6}$ & 1.51 & 1.63 & $1.0 \times 10^{-6}$ & 1.44 & 1.36 \\
\hline Dry run & 0.106 & $5.4 \times 10^{-4}$ & $9.2 \times 10^{-6}$ & 1.65 & 1.43 & $1.7 \times 10^{-5}$ & 1.21 & 1.23 \\
\hline Wet run & 0.104 & $4.0 \times 10^{-4}$ & $5.0 \times 10^{-6}$ & 1.38 & 1.06 & $2.0 \times 10^{-6}$ & 1.09 & 0.83 \\
\hline
\end{tabular}

Table 5. Statistics used to assess the goodness of the model.

\begin{tabular}{llll}
\hline Description & Symbol & Equation & Best fit \\
\hline Root Mean Square Error & RMSE & RMSE $=\sqrt{\frac{1}{n} \sum_{i=1}^{n}\left(O_{i}-P_{i}\right)^{2}}$ & 0.0 \\
Coefficient of Determination & $R^{2}$ & $R^{2}=1-\frac{\frac{1}{(n-2)} \sum_{i=1}^{n}\left(O_{i}-P_{i}\right)^{2}}{\frac{1}{(n-1)} \sum_{i=1}^{n}\left(O_{i}-O_{i} \text { mean }\right)^{2}}$ & 1.0 \\
& & $\mathrm{ME}=1-\frac{\sum_{i=1}^{n}\left(O_{i}-P_{i}\right)^{2}}{\sum_{i=1}^{n}\left(O_{i}-O_{i} \text { mean }\right)^{2}}$ & 1.0 \\
\hline
\end{tabular}

\subsection{Relationship between optimised model parameters and gully characteristics}

The analysis above shows that a simple runoff-infiltration model is quite capable of simulating the observed transmission losses, both in terms of total quantities and temporal dynamics. However, application of such a model in conditions where no experimental data are available would require the estimation of model parameters to which the results are most sensitive with a sufficiently high accuracy, e.g. from observations on vegetation cover in the gully beds and from measurements of gully geometry. 
Pearson correlation analysis between sorptivity, hydraulic conductivity and gully characteristics (gully geometry, vegetation cover, and gully bed material) shows that the relation between sorptivity, $S$, and gully characteristics is relatively weak and sometimes inconsistent with existing knowledge, with correlation coefficients varying between $r=-0.35$ and $r=0.43$ (Table 6). As this might be due to model overparameterization (as both $K$ and $S$ describe the infiltration properties of the gully bed), we carried out a second optimisation procedure whereby we assumed $S$ to be constant and to be equal to the average value obtained during the first optimisation (i.e. $\left.4.46 \times 10^{-4} \mathrm{~m} \mathrm{~s}^{-0.5}\right)$ and only allowed $K$ to vary $\left(=K_{2}\right)$. $K_{2}$ should be regarded as a fitting parameter that accomodates for the observed variations in infiltration: values resulting from optimisation should not be considered to be physically realistic. As expected, this second optimisation resulted in a somewhat lower model performance ( $\mathrm{ME}=0.03$; Table 4 and Fig. 6b). Correlation analysis shows that $K_{2}$ (estimated hydraulic conductivity, after second optimisation) is signficantly related to several gully characteristics with correlation coefficients varying between $r=-0.54$ and $r=0.46$ (Table 6). These characteristics are often interrelated and therefore we used multiple stepwise regression to assess combined effects, resulting in:

$$
\begin{aligned}
& K_{2}=5.18 \times e^{-5}-\left(4.93 E^{-7} \times A S M\right)-\left(7.56 E^{-7} \times \text { Silt }\right) \\
& +\left(2.97 E^{-7} \times V C\right) \\
& \left(R^{2}=0.59, n=16\right)
\end{aligned}
$$

Where ASM is the antecedent soil moisture (\%), Silt is the percentage of silt in the the gully bed material (\%) and $V C$ is the average ground vegetation cover of the gully bed (\%).

The fact that optimised $K_{2}$ values are dependent on the antecedent soil moisture is a logical consequence of assuming a constant sorptivity as transient effects are now accomodated for by variations in $K_{2}$. The positive relationship with vegetation cover is as expected: the presence of vegetation and vegetation residue is known to increase infiltration by protecting the topsoil against sealing and crusting and by enhancing infiltration through macropores due to roots and/or to the activity of animals living in the vicinity of vegetation (Fiener and Auerswald, 2003; Le Bissonnais et al., 2004). Estimated hydraulic conductivity is negatively related to the gully bed's silt content. Several studies have shown that the presence of silt in a topsoil layer may indeed strongly enhance the reduction of infiltration due to sealing and crusting (Poesen, 1986).

We also investigated to what extent simulations of runoff volumes by the model described above agreed with observed values if the hydraulic conductivity estimated by Eq. (11) was used while measured values were used for all other model parameters. Figure $6 \mathrm{c}$ shows that simulations are poor (ME=-1.30). Generally, simulated runoff volumes are of the correct order of magnitude, but the relationship between
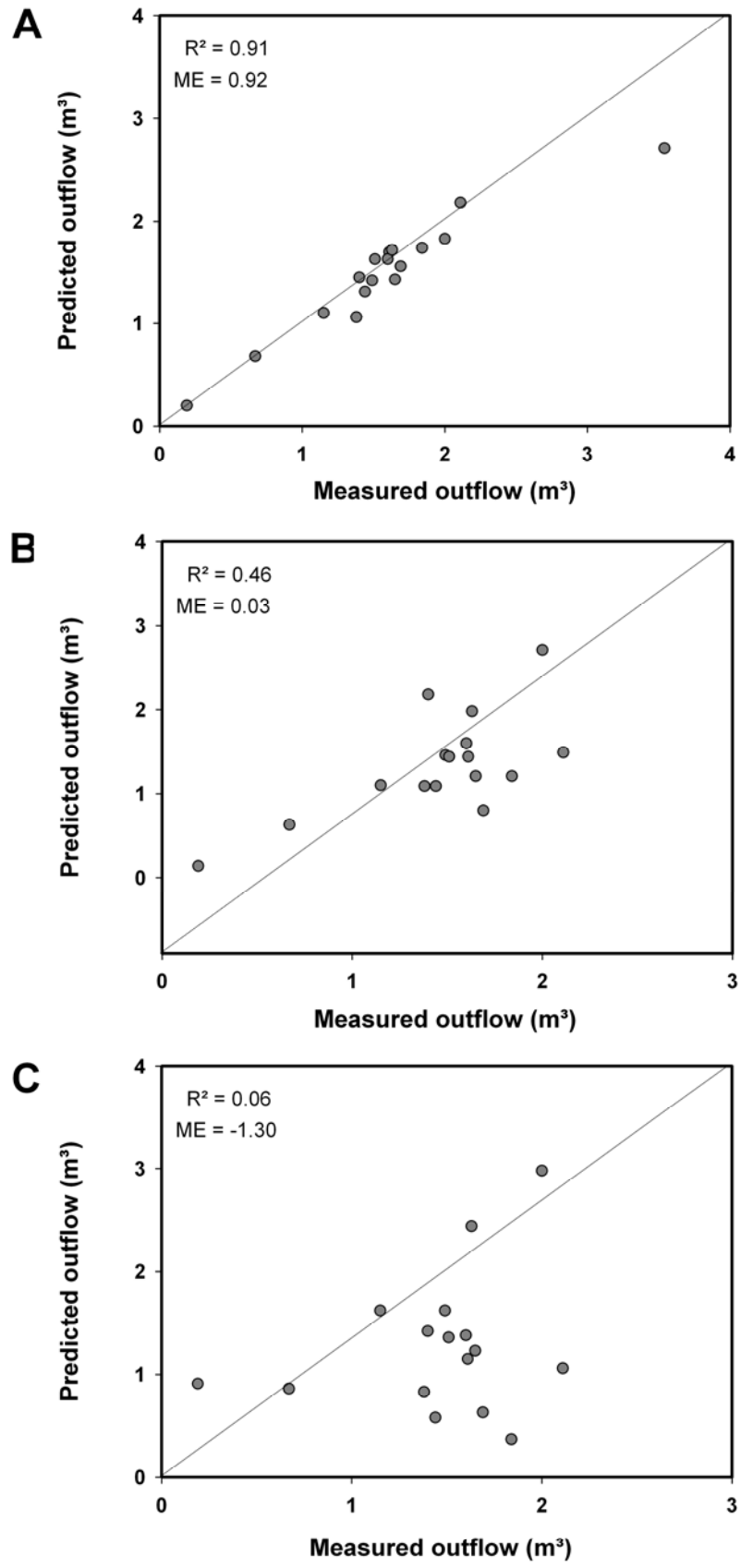

Fig. 6. Plots of measured vs. simulated outflow volume for the 16 runs. (A) Simulated outflow is obtained by calibrating $K$ and $S$ to match the observed outflow hydrograph, (B) Simulated outflow is calculated by keeping the sorptivity, $S$, constant and equal to the average $S$-value obtained from the first model optimisation, and $(\mathbf{C})$ Simulated outflow is calculated using the simulated values of $K_{2}$ from the regression equation (Eq. 12).

simulated and observed runoff volumes is not statistically significant. This is not surprising given the high sensitivity of model output to the estimation of hydraulic conductivity: a change of $\pm 10 \%$ in $K$ results in changes in total 

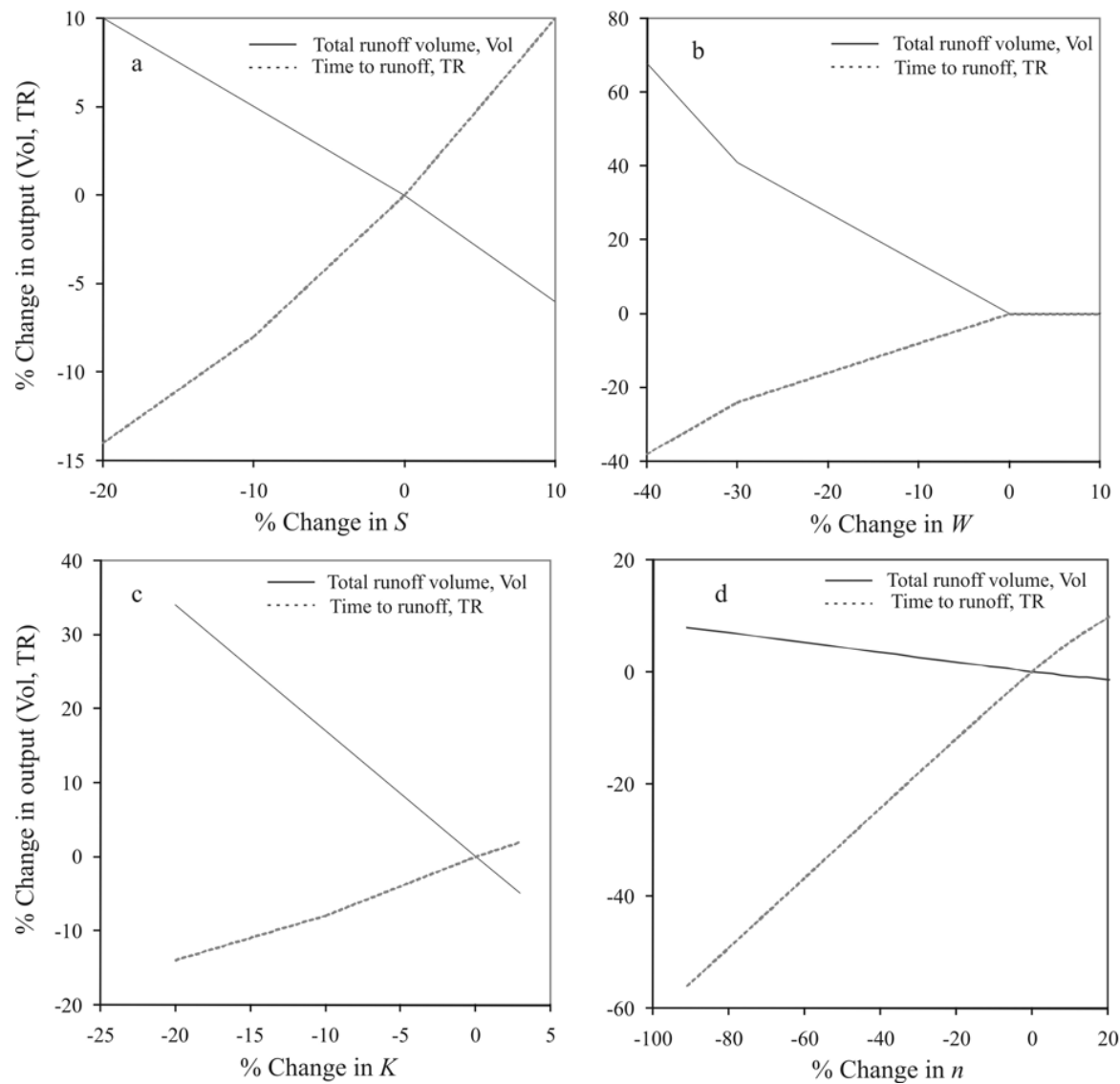

Fig. 7. Sensitivity of the model to changes in the input values of the sorptivity $(S)$, runoff width $(W)$, hydraulic conductivity $(K)$ and Manning's roughness coefficient $(n)$.

Table 6. Pearson correlation coefficients $(n=16)$ between $K, S$ and $K_{2}$, and the gully characteristics. $K_{2}$ is obtained after a second model optimisation keeping the value of sorptivity, $S$, constant. (Note that the values in italics represent the p-values).

\begin{tabular}{lcrrr}
\hline & & $\begin{array}{r}\text { Hydraulic } \\
\text { Conductivity }\end{array}$ & Sorptivity & $\begin{array}{r}\text { Hydraulic } \\
\text { Conductivity }\end{array}$ \\
& & $K$ & $S$ & $K_{2}$ \\
\hline Runoff width & $W$ & -0.043 & -0.354 & 0.085 \\
& & 0.873 & 0.177 & 0.753 \\
Average vegetation cover & $V C$ & 0.303 & -0.157 & 0.371 \\
& & 0.253 & 0.560 & 0.156 \\
Antecedent soil moisture & $A S M$ & -0.505 & -0.147 & -0.544 \\
& & 0.045 & 0.586 & 0.029 \\
Average bed slope & \multirow{2}{*}{$S_{O}$} & 0.425 & -0.217 & 0.457 \\
Sand & & 0.100 & 0.419 & 0.075 \\
& - & 0.334 & -0.122 & 0.326 \\
Silt & & 0.205 & 0.650 & 0.216 \\
& - & -0.546 & 0.243 & -0.394 \\
Clay & & 0.028 & 0.364 & 0.130 \\
& - & -0.121 & 0.015 & -0.213 \\
& & 0.653 & 0.955 & 0.426 \\
\hline
\end{tabular}


runoff output of over 300\% (Fig. 7c). As the standard errors of estimation are well in excess of $30 \%$ for Eq. (11), an accurate simulation of total runoff volume using estimated values of $K_{2}$ cannot be expected. This shows once more that the applicability of process based models in hydrology is often strongly hampered by our inability to accurately estimate parameter values at the scale required, a problem that has often been discussed in the literature (e.g. Beven, 1995).

Although we may not be able to model the response of each individual gully correctly, our analysis does allow to identify the major controls of water transmission losses on vegetated gully beds. These concepts are widely applicable for gully systems in different stages of development. The most important control appears to be the soil moisture status. However, vegetation cover and runoff width also play an important role. The latter two are to some extent interrelated: in a system that is recovering after an intense degradation phase, the re-appearance of vegetation on gully beds will lead to sediment trapping and hence to an increase in runoff width. Any model that aims at reflecting changes in hydrology due to vegetation recovery should therefore incorporate both factors. The model we used may be used to identify trends and estimate the direction and the order of magnitude of change. However, the correct calculation of transmission losses in individual gullies for a given inflow rate appears not to be possible as the necessary input parameter values cannot be estimated with the required accuracy from the available data.

\section{Conclusions}

Concentrated flow experiments in steep gully channels clearly show that the conditions in the gully systems play a pivotal role in the hydrological response of degraded catchments. Gullies with more than 50\% surface vegetation cover exhibit the highest cumulative infiltration coefficients $(81 \%$ for "dry runs", and 34\% for "wet runs"). The efficiency of gully bed vegetation in reducing runoff water transfer is the highest for dry gully beds, i.e. at the beginning of a rainfall event.

Using a coupled kinematic wave-infiltration model allows to simulate the transfer of runoff water well. However, the applicability to simulate transmission losses for gully systems where no experimental data are available can be questionable, as our results indicate that the model results are particularly sensitive to the parameter values of runoff width, hydraulic conductivity and sorptivity. Detailed field measurements of key hydraulic parameters are important, as it remains difficult to accurately simulate parameter values at the scale required for these analyses. Our observations indicate that this is largely related to the high spatial variability in gully bed characteristics.

Statistical analyses indicate that vegetation cover, runoff width and antecedent moisture content are the major controls of water transmission losses in vegetated gully beds. Correlation analysis between optimised parameter values and gully characteristics confirms our experimental results that indicated that ca. $78 \%$ of the variance in cumulative infiltration coefficient was explained by soil moisture content, vegetation cover and runoff width. The interaction of vegetation and runoff width is particularly efficient in retarding surface runoff and enhancing runoff infiltration in dry hydrological conditions. Once the gully bed is wetted, its storage and infiltration capacity are reduced.

The results obtained from the field experiments and the kinematic wave model clearly show that gully systems are key elements in the hydrological connectivity of degraded landscapes, and restoration of gully systems e.g. by vegetation of the channel bed is particularly efficient in reducing water and sediment delivery to the river system. As vegetation in naturally recovering ecosystems is often also most rapidly returning on the gully beds, because of higher water availability and reduced exposure, sediment yield as well as peak discharges in the fluvial system may start rapidly to decline once vegetation recovery is initiated.

Acknowledgements. We thank F. Cisneros, M. Ramirez, and E. Tacuri for facilitating equipment utilisation for the field experiments. This work was supported by an IRO fellowship and a PDM postdoctoral mandate from the K. U. Leuven to A. Molina. This research was done within the framework of the Inter-University Project "Towards integrated catchment management in tropical mountain areas: the problem of sediment management, Paute River, Ecuador" between the University of Cuenca, Ecuador and the K. U. Leuven, Belgium. We thank three anonymous reviewers for their valuable suggestions.

Edited by: E. Zehe

\section{References}

Beck, E., Bendix, J., Kottke, I., Makeschin, F., and Mosandl, R.: Gradients in a Tropical Mountain Ecosystem of Ecuador, Ecological Studies Series 198, Springer Scientific, Berlin, 528 pp., 2008.

Beven, K.: Linking parameters across scales: Subgrid parameterizations and scale dependent hydrological models, Hydrol. Process., 9, 507-525, 1995.

Bracken, L. J. and Croke, J.: The concept of hydrological connectivity and its contribution to understand runoff-dominated geomorphic systems, Hydrol. Process., 21, 1749-1763, 2007.

Bruijnzeel, L. A.: Hydrological functions of tropical forests: not seeing the soils for the trees?, Agr. Ecosyst. Environ., 104, 185228, 2004.

Chow, V. T., Maidment, D. R., and Mays, L. W.: Applied Hydrology, McGraw-Hill, USA, 572 pp., 1988.

Cowan, W. L.: Estimating hydraulic roughness coefficients, Agr. Eng., 37, 473-475, 1956.

Croke, J., Mockler, S., Fogarty, P., and Takken, I.: Sediment concentration changes in runoff pathways from a forest road network 
and the resultant spatial pattern of catchment connectivity, Geomorphology, 68, 257-268, 2005.

Deletic, A.: Modelling of water and sediment transport over grassed areas, J. Hydrol., 248, 168-182, 2001.

Dercon, G., Bossuyt, B., De Bièvre, B., Cisneros, F., and Deckers, J.: Zonificación Agro-ecologica del Austro Ecuatoriano, Programa para el Manejo del Agua y Suelo (PROMAS), Cuenca, Ecuador, 1998.

Fiener, P. and Auerswald, K.: Effectiveness of grassed waterways in reducing runoff and sediment delivery from agricultural watersheds, J. Environ. Qual., 32, 927-936, 2003.

Fiener, P. and Auerswald, K.: Measurement and modeling of concentrated runoff in grassed waterways, J. Hydrol., 301, 198-215, 2005.

Gimenez, R. and Govers, G.: Interaction between bed roughness and flow hydraulics in eroding rills, Water Resour. Res., 37, 791799, 2001.

Govers, G., Gimenez, R., and Van Oost, K.: Rill erosion: Exploring the relationship between experiments, modelling and field observation, Earth-Sci. Rev., 84, 87-102, 2007.

Harden, C. P.: Andean soil erosion: A comparison of soil erosion conditions in two Andean watersheds, Natl. Geogr. Res., 7(2), 216-231, 1991.

Harden, C. P.: Interrelationship between land abandonment and land degradation: a case from the Ecuadorian Andes, Mt. Res. Dev., 16, 274-280, 1996.

Harden, C. P.: Human impacts on headwater fluvial systems in the Northern and Central Andes, Geomorphology, 79, 249-263, 2006.

Hillel, D.: Environmental Soil Physics, Academic Press, San Diego, CA, 1998

Hungerbühler, D., Steinmann, M., Winkler, W., Seward, D., Eguez, D., Eguez, A., Peterson, D. E., Helg, U., and Hammer, C.: Neogene stratigraphy and Andean geodynamics of southern Ecuador, Earth-Sci. Rev., 57, 75-124, 2002.

Jaber, F. H., and Mohtar, R. H.: Stability and accuracy of finite element schemes for the one-dimensional kinematic wave solution, Adv. Water Resour., 25, 427-438, 2002.

Janeau, J. L., Bricquet, J. P., Planchon, O., and Valentin, C.: Soil crusting and infiltration on steep slopes in northern Thailand, Eur. J. Soil Sci., 54, 543-553, 2003.

Le Bissonnais, Y., Lecomte, V., and Cerdan, O.: Grass strip effects on runoff and soil loss, Agronomie, 24, 129-136, 2004.

Lighthill, M. J. and Woolhiser, D. A.: Modern approach to design of grassed channels, J. Irrigat. Drain. Eng. ASCE., 118, 733-743, 1955.

Lopez, F. and Garcia, M. H.: Mean flow and turbulent structure of open-channel flow through non-emergent vegetation, J. Hydraul. Eng., 127, 392-402, 2001.

Molina, A., Govers, G., Vanacker, V., Poesen, J., Zeelmaekers, E., and Cisneros, F.: Runoff generation in a degraded Andean ecosystem: Interaction of vegetation cover and land use, Catena, 71, 357-370, 2007.
Molina, A., Govers, G., Cisneros, F., and Vanacker, V.: Vegetation and topographic controls on sediment deposition and storage on gully beds in a degraded mountain area, Earth Surface Processes and Landforms, 34, 755-767, doi:10.1002/esp.1747, 2009.

Muñoz-Carpena, R., Miller, C. T., and Parsons, J. E.: A quadratic Petrov-Galerkin solutions for kinematic wave overland flow, Water Resour. Res., 29(8), 2615-2627, 1993.

Muñoz-Carpena, R., Parsons, J. E., and Gilliam, J. W.: Modeling hydrology and sediment transport in vegetative filter strips, J Hydrol., 214, 111-129, 1999.

Nachtergaele, J., Poesen, J., Wijdenes, D. O., and Vandekerckhove, L.: Medium-term evolution of a gully developed in a loessderived soil, Geomorphology, 46(3-4), 223-239, 2002.

Philip, J. R.: Theory of infiltration, Adv. Hydrosci., 5, 215-296, 1969.

Poesen, J.: Surface sealing as influenced by slope angle and position of simulated stones in the top layer of loose sediments, Earth Surf. Proc. Land., 11, 1-10, 1986.

Prosser, I., Dietrich, W., and Stevenson, J.: Flow resistance and sediment transport by concentrated overland flow in a grassland valley, Geomorphology, 13, 71-86, 1995.

Rey, F.: Influence of vegetation distribution on sediment yield in forested marly gullies, Catena, 50, 549-562, 2003.

Rey, F.: Effectiveness of vegetation barriers for marly sediment trapping, Earth Surf. Proc. Land., 29, 1161-1169, 2004.

Seibert, J. and McGlynn, B.: Landscape element contributions to storm runoff, in: Encyclopedia of Hydrological Sciences, edited by: Anderson, M. G., Wiley, Chichester, UK, 1751-1761 pp., 2005.

Temple, D. M.: Flow retardance of submerged grass channel linings, T. Am. Soc. Agr. Eng., 25, 1300-1303, 1982.

Temple, D. M.: Design of grass-lined open channels, T. Am. Soc. Agr. Eng., 26, 1064-1069, 1983.

Tsujimoto, T.: Fluvial processes in streams with vegetation, J. Hydraul. Res., 37, 789-803, 1999.

Vanacker, V., Govers, G., Barros, S., Poesen, J., and Deckers, J.: The effect of short-term socio-economic and demographic changes on land-use dynamics and its corresponding geomorphic response with relation to water erosion in a tropical mountainous catchment, Ecuador, Landscape Ecol., 18, 1-15, 2003.

Vanacker, V., von Blanckenburg, F., Govers, G., Molina, A., Poesen, J., Deckers, J., and Kubik, P.: Restoring natural vegetation reverts mountain erosion to natural levels, Geology, 35, 303-306, 2007.

White, S. and Maldonado, F.: The use and conservation of national resources in the Andes of southern Ecuador, Mt. Res. Dev., 11, 37-55, 1991.

Ziegler, A. D., Giambelluca, T. W., Plondke, D., Leisz, S., Tran, L. T., Fox, J., Nullet, M. A., Vogler, J. B., Troung, D. M., and Vien, T. D.: Hydrological consequences of landscape fragmentation in mountainous northern Vietnam: Buffering of Hortonian overland flow, J. Hydrol., 337, 52-67, 2007. 